\title{
Family farming policy network in Brazil
} \author{
Diego MOTA VIEIRA ${ }^{2}$ \\ Daniela Matias de Carvalho BitTencourt ${ }^{3}$ \\ 1 TRIBUnAL de CONTAS dA UniÃo (TCU), BRASílIA - DF, BRAZIL \\ 2 Universidade de Brasília (UnB) / Programa de Pós-Graduação em AdMinistração, BrasílıIA - DF, BraziL \\ ${ }^{3}$ EMpresa Brasileira de Pesquisa Agropecuária (EMBRAPA) / ReCursos Genéticos e BioteCnologia, Brasília - DF, BRAZIL
}

LUCIANA NUNES GOULART ${ }^{1}$

\begin{abstract}
This paper presents a public policy network analysis carried out on the Brazilian National Family Farming Policy. The study collected data through documentary review, budget consultations, and interviews, submitting the obtained information to content analysis. The results identified the constitution of the network of actors involved in policy management, as well as the characteristics of the relationships established among them. This type of analysis is an important instrument for studies on the implementation and evaluation of public policies, as it shows how the characteristics of interactions between actors can affect the success of public policies. The National Family Farming Policy network, at the time of the research, was dense at its center and flexible at its margins, meaning that it was formed by an important set of actors concurrently working in several programs and another set of more localized actors. Nonetheless, both at the center and at the margins, it was observed that several actors are not always as active as expected. Based on the public policy networks analysis theoretical framework, it is suggested that such a situation compromises the network's functioning and the outcome of the underlying policies. Moreover, the network characteristics reinforce the importance of the federative pact for the functioning of family farming policy in Brazil and show that the interests and demands of subnational managers should be effectively considered to achieve the expected results.
\end{abstract}

Keywords: Public policy networks. Family farming. Network relationships..

\section{A rede da Política Nacional de Agricultura Familiar no Brasil}

\begin{abstract}
Resumo
Este artigo apresenta uma análise de redes de políticas públicas com foco na Política Nacional de Agricultura Familiar no Brasil. O estudo coletou dados por meio de análise documental, consultas orçamentárias e entrevistas, submetendo as informações obtidas a análise de conteúdo e, com isso, identificou a composição da rede de atores envolvidos na gestão da política, bem como as características das relações estabelecidas entre eles. Esse tipo de análise constitui interessante instrumento para os estudos de implementação e de avaliação de políticas públicas, na medida em que evidencia de que modo as características da interação entre atores podem afetar o alcance dos objetivos das políticas públicas. A rede da Política Nacional de Agricultura Familiar existente à época da pesquisa se mostrava densa em seu centro e flexível em suas margens, ou seja, era formada por um importante conjunto de atores atuando de modo concomitante em diversos programas e outro conjunto de atores atuando de modo mais pontual ou localizado. Porém, tanto no centro quanto nas margens, observou-se que diversos atores nem sempre são tão atuantes quanto seria esperado. Assim, com base no referencial teórico de análise de redes de políticas públicas, sugere-se que tal situação compromete o funcionamento da rede e o resultado das políticas subjacentes. Ademais, as características da rede estudada demonstram a importância do pacto federativo para o funcionamento da Política Nacional de Agricultura Familiar e mostram que os gestores subnacionais devem ter seus interesses e demandas efetivamente considerados para que os resultados almejados sejam atingidos.
\end{abstract}

Palavras-chave: Redes de políticas públicas. Agricultura familiar. Relações em rede.

\section{La red de la Política Nacional de Agricultura Familiar en Brasil}

\section{Resumen}

Este artículo presenta un análisis de redes de políticas públicas enfocado en la Política Nacional de Agricultura Familiar de Brasil. El estudio recolectó datos a través del análisis documental, consultas presupuestarias y entrevistas, sometió la información a análisis de contenido y, de esa manera, identificó la composición de la red de actores involucrados en la gestión de la política, así como las características de las relaciones establecidas entre ellos. Este tipo de análisis es un instrumento interesante para estudios de implementación y de evaluación de políticas públicas, ya que muestra cómo las características de interacción entre actores pueden afectar el logro de los objetivos de las políticas públicas. La red de la Política Nacional de Agricultura Familiar existente en el momento de la investigación era densa en su centro y flexible en sus márgenes, es decir, estaba formada por un conjunto de actores que operaban simultáneamente en varios programas y otro conjunto de actores que operaba de manera más puntual. Sin embargo, tanto en el centro como en los márgenes, se observó que varios actores no siempre fueron tan activos como se esperaba. Por lo tanto, con base en el marco teórico de análisis de redes de políticas públicas, se sugiere que esta situación compromete el funcionamiento de la red y el resultado de las políticas subyacentes. Además, las características de la red estudiada demuestran la importancia del pacto federativo para el funcionamiento de la Política de Agricultura Familiar brasileña y muestran que los intereses y demandas de los gestores subnacionales deben ser efectivamente considerados para lograr los resultados deseados.

Palabras clave: Redes de políticas públicas. Agricultura familiar. Relaciones en red. 


\section{INTRODUCTION}

In their classic work on implementation of public policy, Pressman and Wildavsky (1984, p. 133) affirm that the most frequent recommendation for governmental action is "what we need is more coordination" and no complaint about public services is as frequent as a "lack of coordination". According to Jennings (1994), the concept of coordination has become one of the most discussed subjects in the literature both about organizations and public policy, due to the more and more complex nature of issues that the public sector faces (Ferlie, Fitzgerald, McGivern \& Dopson, 2011; O'Toole, 1997; Peters, 1998; Repetto, 2009).

In fact, it's notable that public administration frequently seeks to organize itself through the connected actions of various actors in contexts in which traditional hierarchies have little value and organization's mandates have lots of intersections. These interactive contexts are termed public policy networks by the literature (O'Toole, 1997; Provan \& Milward, 1995).

These networks operate in contexts in which incentives are present for cooperation as well as for isolated action - mainly when different programs and agencies are created over time to meet similar or even overlapping needs (Cline, 2000; Jennings \& Ewalt, 1998).

Considering this fact, this study analyzes the composition of the relationships of the National Family Farming Policy Network in Brazil. It faces important challenges in terms of coordination which makes it appropriate to apply social network analysis (SNA) to it. The approach has tools to identify aspects such as the power and capacity to access resources through the positional and relational characteristics of actors in a semi-stable institutional context of cooperation relationships in search of given objectives (Burt, 1992; Borgatti, Everett \& Johnson, 2013; Fischer \& Sciarini, 2015; Leifeld \& Schneider, 2012).

As we consider it is crucial to understand the origins of family farming in this country - to comprehend its current needs and its immense social complexity - this article will begin with a presentation of the historical antecedents that led to the formation of the National Family Farming Policy Network in Brazil. Then, we will describe the methodology which made it possible to identify the composition and characteristics of network relationships - presented in later sections. Finally, we will present some of the implications of the research findings and indicate possible solutions to improve the functioning of this network.

\section{HISTORICAL ANTECEDENTS OF FAMILY FARMING POLICY IN BRAZIL}

The Land Statute (Lei n. 4.504, 1964, art. 4을 II) defined a family property

[...] as a rural property which, directly and personally worked on by a farmer and his family, absorbs all of their work, guaranteeing them subsistence and social and economic progress, with a maximum area fixed for each region and type of farming, and sometimes work with the help of third parties.

The definition provided by the Land Statute (Lei n. 4.504, 1964) was the first legislation about this subject and has proved important as having delineated criteria in the definition of family properties which are still in use today. However, it is important to return even more to the past to understand family farming as a social phenomenon, going beyond its legal definitions. Thus, the rural family working model in Brazil originated during the colonial period, with large properties and the subservience of field workers (Guanziroli, 1999; Moreira, 2009; Picolotto, 2014).

According to Moreira (2009), the fact that Brazilian rural workers appeared in a subaltern position led to stigmatization and its association with images of stagnation and conformism. Thus, the rural working market originated in an undervalued socio-economic manner, related just to subsistence farming and backup workforce (Picolotto, 2014). This, in the vision of the author, helps us understand why it was only in the mid- $20^{\text {th }}$ century that political representation organizations for disfavored rural groups arose.

With the beginning of the political opening during the phase of democratization, the field witnessed an expressive social mobilization. There was a certain approximation between the State and rural social organizations given that in the Sarney administration, the Ministry of Agrarian Reform and Development was created and the first National Agrarian Reform Plan 
was presented (Dias, 2007). Moreover, the Federal Constitution of 1988 equalized the rural and the urban worker in terms of assistance and retirement, despite having limited the possibilities of significant changes in the Brazilian land structure, maintaining land access as defined previously by the Land Statute of 1964 (Da Ros, 2006).

Soon after the Constituent Assembly, Law 8,171/1991 concerning agricultural policy was published. Some of the demands of small producers were incorporated in this law, which recognized the diversity of Brazilian farmers and foresaw the construction of a differentiated agricultural policy for small-scale producers. However, the advances did not address all the issues and the interests of large farming sectors prevailed (Fernandes, 2016; Grisa \& Schneider, 2014; Picolotto, 2014).

In the same sense, Law no. 8,629 (Lei n. 8.629, 1993) regulated constitutional provisions regarding agrarian reform and defined the concepts of productive properties and small and medium-sized properties - which, in theory, are not subject to disappropriations. This law sought to discourage invasions and lad conflicts through significant punishments (BRASIL, 1993, art. 2으, $\S \S 6^{\circ}$ and $7^{\circ}$ ) and maintained a good portion of the regulatory structure created by the Land Statute (Lei n. 4.504, 1964).

Later in the 1990s a technical cooperation project was developed between the National Institute of Colonization and Agrarian Reform (INCRA) and the Food and Agriculture Organization of the United Nations (FAO), with the objective of producing the outline of a National Family Farming Policy. The INCRA/FAO study identified family farming as a very heterogeneous group, forming 3 large subgroups: a) peripheral; b) transitional; and c) consolidated.

The peripheral group are low income farmers who normally live in very small areas. In the Incra/FAO model, this group should be target mainly of assistance policies, because "it presents few perspectives for subsistence and development within the context of farming and agrarian policies" (Guanziroli, 1999, p. 16). The transitional group, in turn, is made up of families with income similar to the average income in Brazil and above the income of temporary agricultural workers. Consolidated producers meanwhile have high income with the capacity to generate their own development, and therefore they do not need direct governmental support (Guanziroli, 1999).

The Incra/FAO study assumed great importance, because it defined who should be the target public of the first program that officially addressed family farming in Braszil: the National Program for the Strengthening of Family Farming (Pronaf) (Cazella et al., 2016; Guanziroli, 1999; Picolotto, 2014). Pronaf arose to address the needs mainly of the transitional group, due to its significant potential for economic growth and consolidation (Guanziroli, 1999).

The heterogeneity of the family farming category presents the government with a complex problem, which demands different solutions for diverse groups, also taking into account regional peculiarities and the role of states and municipalities. In this sense, Moreira (2009) argues that the use of the general category family farmers obscures their different social forms as well as their regional differences. In the words of Guanziroli (1999, p. 19):

Family farmers and settlers constitute a heterogeneous public, which is diversified and complex, requiring differentiated solutions. There are rural landowners, rural partners, tenants, part-time workers, day laborers, permanent salaried workers, temporary workers, unemployed field hands, children of small farmers, small landholders, the settlers of the agrarian reform and consolidated family farmers. The proposal cannot be equal for all of them. Some already possess land, such as the small landholders, however [,] they are of small size, other have precarious ownership as rural landowners or partners, and others basically need infrastructure.

The process in which a network of actors became involved to create a specific program for family farming is described in Navarro (2010). The author relates that the movement took shape when, within the context of the implementation of the Southern Common Market (Mercosul) ${ }^{1}$, small producers from Uruguay, Paraguay and Brazil, feeling excluded from the negotiations, allied themselves to seek governmental support. It was in this context that "family farming entered the political scenario as an expression in the national agenda" (Navarro, 2010, p. 192).

According to Navarro (2010), it was up to the National Confederation of Rural Workers (Contag) to lead this process. Contag became the legitimate spokesperson in discussions with the then Ministry of Agriculture, Supply and Agrarian Reform (MAARA) (Caume, 2009; Navarro, 2010). With this approximation, MAARA edited Ministerial Decree no. 692/1993, creating a

${ }^{1}$ Created by the Treaty of Asuncion in 1991. 
working group with the participation of Contag. This group presented a proposal, signed by President Itamar Franco in 1994, denominated the Viability Program for Small Properties, which permitted the creation of Pronaf (Navarro, 2010).

During this process, the government recognized the family farming category as having needs that had to be met by public policy. Thus, in 1999 the National Board of Sustainable Rural Development (Condraf) and the Ministry of Land Policy and Family Farming were created, latter becoming the Ministry of Agrarian Development (MDA) in 2000 (Caume, 2009).

It should be noted that the context in which the program was created was responsible for defining the focus of activities that even today characterize Pronaf, which operates for the concession of financial subsidies to production projects. In this format, the program is very good at meeting the needs of the southern farmers in the country, who were the actors who were mobilized during its creation, since they were most affected by the creation of Mercosul. Thus, even today the policy has characteristics that reflect the context of its formation.

After the consolidation of Pronaf, various other programs related to family farming were created during the first decade of the new century. Moreover, Law no. 11,326/2006 was approved, legally defining the family farming category and establishing other guidelines. Currently there are various actors involved in the management of a variety of programs, characterizing a true network of public policy under the terms defined by Provan and Milward (1995): it includes all organizations - governmental or not - which provide public services to a given target public.

In addition, based on the criteria of Mitchell, Agle and Wood (1997), concerning the attributes of power, legitimacy and urgency, this study also has researched the external stakeholders of the network, understood to be those organizations which, even though they don't provide public services directly to the target public, have influential relationships with the network and need to receive signifficant attention from its managers.

\section{METHODOLOGY}

That being said, we will present a brief description of the methodology utilized to identify members and external stakeholders and the characteristics of the relationships that these actors established within the context of the network.

To accomplish this, we began a documental analysis of the laws, decrees, plans and other official documents which define the attributions of network members and/or present relevant links with stakeholders. One type of document which proved to be quite useful in the identification of network relationships, because it indicates the actions and relationships between the various actors, was the 2018 Monitoring of the Multiyear Plan, available in the Integrated System of Planning and Budgeting (SIOP). This document is rich in information provided by the managers themselves and presents their main achievements and difficulties in terms of implementation.

Moreover, we realized budgetary consultations for 51 actions related to family farming in order to confirm the budgetary units and the managerial units responsible for the use of public resources for this target public ${ }^{2}$. In parallel, we analyzed the composition of various relevant forums ${ }^{3}$ and conducted in-depth interviews with semi-structured scripts with key actors within and outside of the government.

Here is some information about these interviews. First, we conducted a pilot interview, in June 2018, with one of the principal managers of national policy at the time. Later, we conducted interviews between October and December 2018, with a total of 29 managers or stakeholders. All of the interviews, with an average duration of an hour, were taped and transcribed in their entirety.

\footnotetext{
${ }^{2}$ The budgetary consultations were conducted within the federal government's Integrated System of Financial Administration (Siafi), for the years 2013 to 2018, using the Treasury Management website.

${ }^{3}$ National Board of Sustainable Rural Development (Condraf); National Board of Food and Nutrition Security (Consea); National Board of Agro-Ecology and Organic Production (CNAPO); Steering Committees of the Water for All and of the Safra Guarantee Programs; Consultative Groups of the Food Acquisition Program (PAA) and the National Program of Food for Schools (PNAE); and the Administrative Board of the National Agency of and Rural Technical Assistance (ANATER) and the Consulting Board of ANATER.
} 
The interviews were submitted to content analysis, as were the other documents used in the research, following the methodology proposed by Bardin (2009), which makes it possible to systematically categorize a group of data (categories established a priori, based on the theoretical references and the research's objectives), to facilitate the understanding of relevant information.

With the obtained information, we proceeded to register the relationships involved for each one of the principal federal public programs concerned with family farming, through the SNA methodology (Burt, 1992; Borgatti et al., 2013; Fischer \& Sciarini, 2015; Leifeld \& Schneider, 2012). A total of 30 main programs or actions were identified, whose underlying relationships were documented and processed using the Gephi software (The Gephi Consortium, c2017), a free platform that makes it possible to visualize dynamic graphs which assist in the understanding of the format of networks, through automatic calculations and the interpretation of metrics (Bastian, Heymann \& Jacomy, 2009). The use of software made it viable to obtain statistics regarding the network density and the position and centrality of its members (Blondel, Guillaume, Lambiotte \& Lefebvre, 2008; Brandes, 2001; Brin \& Page, 1998).

It should be made clear that the results presented here reflect the network as it existed at the end of 2018, when this study was conducted. The alterations brought about by the Bolsonaro administration through Provisionary Measure no. 870/2019, occurred after the data collection process was completed, and therefore it was out of the analyzed scope. However, the analytical loss may be considered minor, given that it is not difficult to reposition the relevant actors within the new structure.

\section{COMPOSITION OF THE NATIONAL FAMILY FARMING POLICY NETWORK}

With the application of the methodology described, 171 participants were identified, between members and external stakeholders of the National Family Farming Policy Network. Table 1 summarizes this composition.

Table 1

Composition of the National Family Farming Policy Network

\begin{tabular}{ccccc} 
& Government & $\begin{array}{c}\text { Civil society/ } \\
\text { private sector }\end{array}$ & Total & Percentage \\
\hline Members & 65 & 11 & 76 & $44.4 \%$ \\
\hline External Stakeholders & 28 & 67 & 95 & $55.6 \%$ \\
\hline Total & 93 & 78 & 171 & \\
\hline Percentage & $54.4 \%$ & $45.6 \%$ & & $100 \%$ \\
\hline
\end{tabular}

Source: Elaborated by the authors.

In reality, the number of participating organizations is much larger. This is because "municipal governments", for example, were treated as a single entity, since their interests and attributions in relation to the national network may be considered relatively homogeneous. For the same reason, "ATER private entities" were treated as a single fictitious organization which, in truth, represents hundreds of companies spread all over the country ${ }^{4}$, among other cases. Thus, the 171 participants represent in some cases organizations and in other cases types of organizations, which reinforces the complexity of the real network.

In any event, even with these simplifications, the identified network is quite large. This is a relevant aspect, given that the literature points out that there is a limit to the number of links that a given organization can manage effectively (Mitchell \& Shortell, 2000; Provan \& Kenis, 2007; Provan \& Milward, 1995). Thus, even considering that the actors are not connected to all the other actors, the elevated number of members and external stakeholders indicates that these organizations may be incurring in high management costs (Berardo, 2009; Leifeld \& Schneider, 2012). Moreover, very large networks demonstrate a greater tendency to have overlapping activities (Raab, Mannak \& Cambré, 2013), which compromises the economic efficiency of public spending.

\footnotetext{
${ }^{4}$ On January 27, 2019 there were 316 companies accredited by ANATER, according to a consultation of the ATER Management System.
} 
After identifying the composition of the network, we made a brief analysis of its level of heterogeneity. According to Mitchell and Shortell (2000), a network is more heterogeneous to the extent that it possesses more actors of the private sector and civil society in its composition. To the authors, the more complex the problems that the network deals with, the greater its level of heterogeneity needs to be, because with the presence of different types of actors, it becomes possible to weigh legitimacy and results (Mitchell \& Shortell, 2000).

In the case of the National Family Farming Policy Network, the view offered in Table 1 makes it possible to affirm that this is quite a heterogeneous network, with a variance equal to 0.248 , very close to the maximum variance between two binary variables $(0.25)^{5}$.

However, given the specificity of this case, it is considered pertinent to differentiate organizations that represent family farming and other private organizations, between non-governmental actors, as shown in Table 2.

Table 2

Highlighting the Organizations that Represent Family Farming within the Composition of the Network

\begin{tabular}{cccc}
\hline Government & $\begin{array}{c}\text { Various Private } \\
\text { Actors }\end{array}$ & $\begin{array}{c}\text { Organizations Representing } \\
\text { Family Farming }\end{array}$ & Total \\
\hline 93 & 43 & 35 & 171 \\
\hline $54.4 \%$ & $25.15 \%$ & $20.45 \%$ & $100 \%$ \\
\hline
\end{tabular}

Source: Elaborated by the authors.

Thus, it may be perceived that organizations representing family farming correspond to less than $21 \%$ of the participants identified in this study ${ }^{6}$, which may lead to lower levels of legitimacy of the network (Mitchell \& Shortell, 2000).

In addition, and considering the important role performed by Condraf, because it "proposes guidelines for the formulation, implementation and execution of structured public policies concerned with sustainable rural development, agrarian reform, land reorganization, and family farming" (Decreto n. 9.186, 2017, art. 19)7, we analyzed the evolution of the composition of this board since its creation, in relation to the participation of governmental actors and organizations representaing family farming ${ }^{8}$.

Condraf was created by Decree no. 3,200/1999 and went through various alterations with Decrees no. 3,508/2000; 3,992/2001; $4,854 / 2003 ; 8,735 / 2016$ and $9,186 / 2017$. The graphs which follow were elaborated based on these norms. The first presents, for each successive composition, the number of members with voting rights.

In Figure 1, it may be noted that the participation of organizations representing family farming, among the members of Condraf, increased until its apex with Decree no. 8,735/2016. It should be emphasized that the composition crystalized by this norm was the fruit of a study to restructure the board developed by a working group ${ }^{9}$ formed to propose a more updated structure to suit the needs of family farming at the time. However, the composition defined by decree in 2016 was not put into practice, because the board was paralyzed for two years after the impeachment of President Dilma Rousseff. Under the administration

\footnotetext{
${ }^{5}$ The maximum variance between binary variables is obtained by the multiplication of the percentages of the 2 categories, in this case: 0.456 (non-governmental) $\times 0.544$ (governmental) $=0.248$.

${ }^{6}$ It is possible that there are others of the various types that do not appear in this data collection strategy.

${ }^{7}$ Decree no. 9,186/2017 was revoked by Decree no. 9,759/2019, which extinguished 55 federal government bodies, including Condraf.

${ }^{8}$ This analysis did not consider organizations which, even though they are not exactly governmental, have strong formal ties to the government and/or that, even though they represent civil society, cannot be considered representatives of family farming. The organizations which were not considered for the analysis presented in Figures 1 and 2 were during this period are: National Forum of Agriculture Secretaries, Brazilian Micro and Small Business Support Service (Sebrae), National Association of State Land Organs (Anoter), municipal associations, Brazilian Association of Public Entities of Rural Technical Assistance (Asbraer), National Board of State Rural Research Entities (Consepa) and the National Board of the State Secretariats of Agriculture (Conseagri), which are non-governmental organs that have strong formal ties to the government. We also did not consider the National Board of Food and Nutrition Security (Consea) and the National Board of Agro-Ecology and Organic Production (CNAPO) which, even though they are institutions which are greatly influenced by family farming interests, are organs directly linked to the government.

${ }^{9}$ Formed by representatives of the National Confederation of Rural Workers (Contag), National Confederation of Workers and Family Farmers of Brazil (Contraf Brasil), National Conference of Brazilian Bishops (CNBB), Brazilian Semiarid Articulation (ASA), Rotation Rural Schools Network (CEFFAS Network) and the Ministry of Agrarian Development (MDA), according to the 60th Ordinary Meeting of Condraf on May 13 and $14,2015$.
} 
of Michel Temer, and before the board met again, a new composition was established by Decree no. 9,186/2017, in which participation became equal, with 22 members from each of the groups.

Figure 1

Composition of Condraf since its creation - just members (with the right to vote)

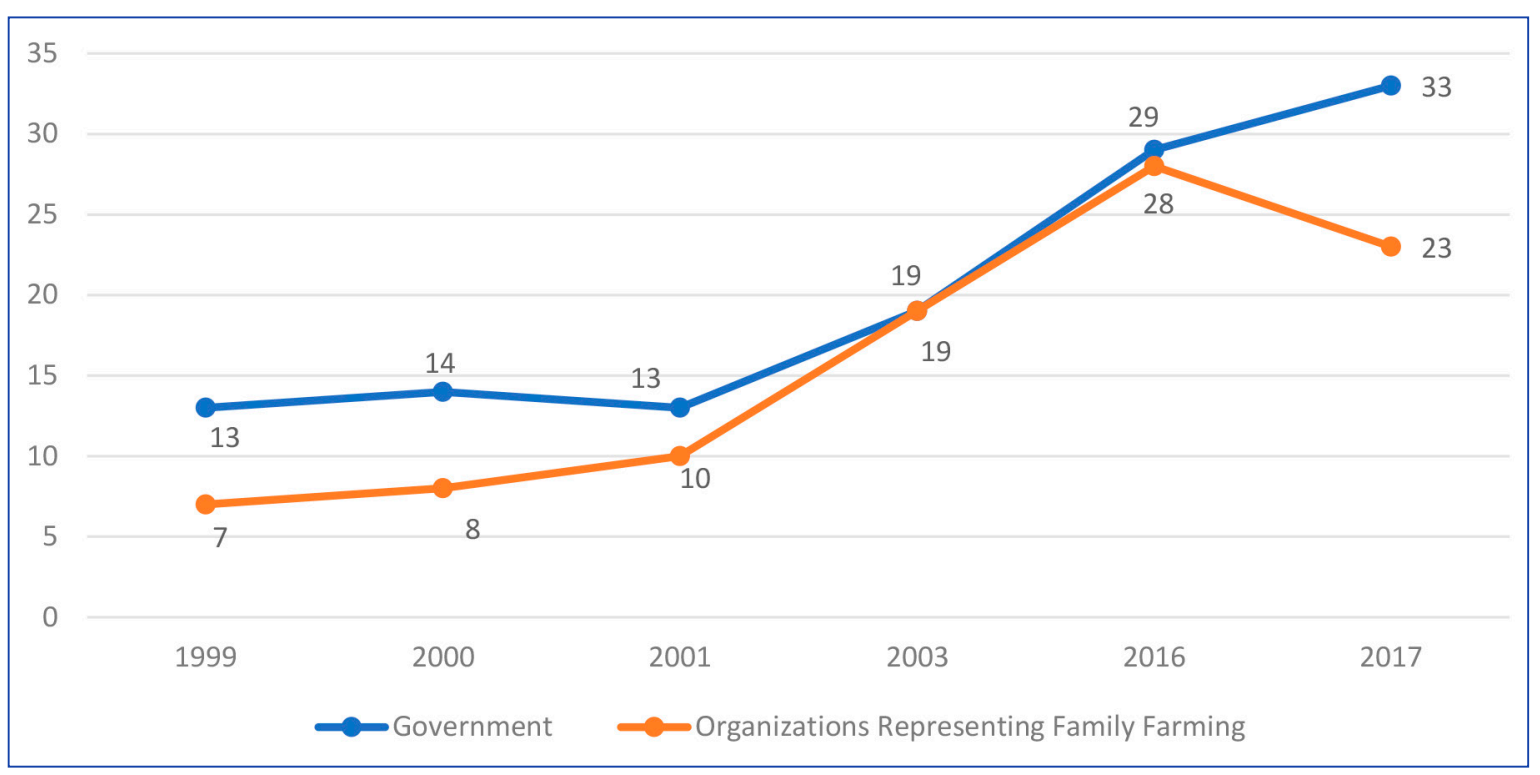

Source: Elaborated by the authors.

However, according to Interviewee 15, the composition formed by the decree of 2017 was not in fact equal, due to the existence of a series of invited organizations which, in their majority, are governmental. According to this interviewee, even though they did not have the right to vote, the guests participated equally in the discussions, and were able to make them unbalanced. That being so, we have also prepared Figure 2 which presents the evolution of Condraf over time considering the presence of invitees (without the right to vote).

Figure 2

\section{Composition of Condraf since its creation - including invitees}

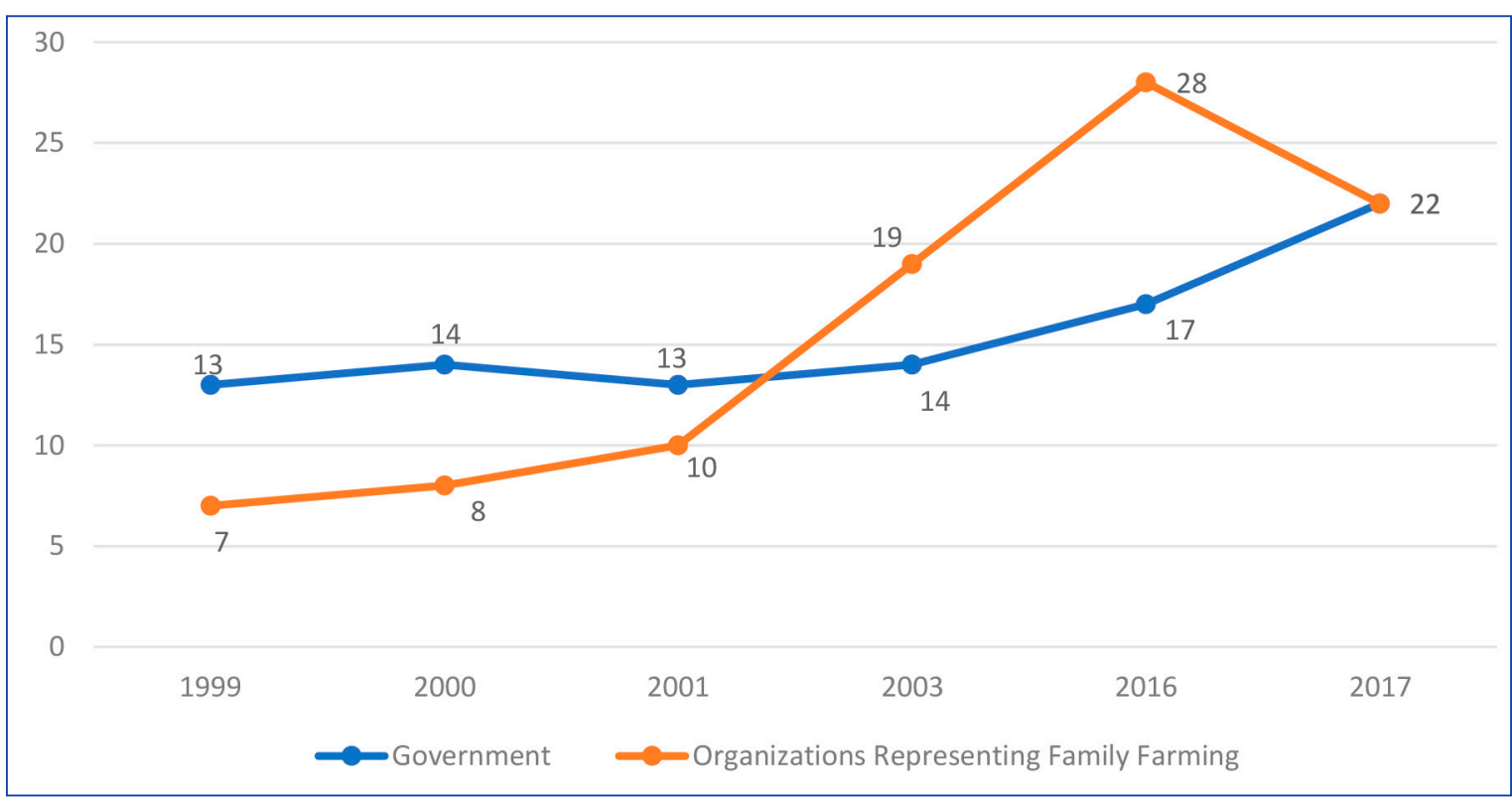

Source: Elaborated by the authors. 
Thus, when the invited organizations are considered, we may percieve a predominance of the government in every period, with more equilibrium between 2003 and 2016, but with a great difference in the composition at the time of this study.

In addition to these observations, another point in terms of the composition of the network should be highlighted. According to the literature, it should be evaluated whether all of the relevant participants are included in the network, because more adherent networks should present greater capacity in obtaining resources (Mandell \& Keast, 2007; Mitchell \& Shortell, 2000).

According to the perception of the various interviewees, the composition of the network was appropriate, despite the fact that the resprentation of some of the sectors was weak and the commitment of various actors was variable. According to Interviewee 24,

[...] the network includes the appropriate actors [...] it's difficult to think of someone who is totally unspoken for, without the ability to express themselves.

Or, in the words of Interviewee 29 ,

\section{[...] the problem is not that the organizations are not present, it is that their performance is deficient.}

In fact, as pointed out by Interviewee 2, even the participation of minorities was also appropriate (for example, women, youths and traditional communities).

\section{CHARACTERISTICS OF THE NETWORK RELATIONSHIPS}

Using the Gephi software (The Gephi Consortium, c2017), we have elaborated the graphs which schematically represent the National Family Farming Policy Network. Figure 3 shows the programs and their main actors. Figure 4 presents the relationships between the actors, based on the programs in which these actors act jointly. Figure 5 presents the relationships between these programs based on their actors in common.

The different colors in the graphs represent the formation of clusters - groups with homogeneous internal characteristics and different characteristics in relation to the others. In the graphs, being part of the same cluster indicates thematic pertinance between the programs and/or points to the joint actions of actors. The proximity between actors also indicates the intensity of their connections in various programs. The diameter of the nodes indicates the centrality of actors and/or programs, and this measurement is strongly related to its degree of importance within the network (Berardo, 2009; Fischer \& Sciarini, 2015; Leifeld \& Schneider, 2012).

The Gephi software (The Gephi Consortium, c2017) also returns statistics which support the construction of the graphs. In this article, in the interest of being concise, just a few of these statistics are highlighted, beginning with the obtained densities.

The literature concerning public policy networks indicates that in dense and well-integrated networks, the services offered tend to be constructed in a complementary manner, so that the entire gamut of needs is covered without any overlapping. Moreover, the more integrated a given member of the network is, the greater is the level of importance attributed by this actor to the network (Provan \& Milward, 1991, 1995).

The program and actor network (Figure 3) presents a density of 0.019 , the actor network (Figure 4) presents a density of 0.269 and the program network (Figure 5) presents a density of 0.979 . The high density of the program network indicates that the National Family Farming Policy presents a group of central actors which act in a strong partnership and in a concomitant manner in many programs, while the low densities obtained in the representations that consider the participation of the actors (Figures 3 and 4) indicate that the central goup is accompanied by a large group of actors that have specific localized and/or dispersed actions. Thus, as characterized by Provan and Lemaire (2012), it is an integrated network in its center and flexible on its margins, which in theory favors the articulation and capacity of the network to generate good results.

In terms of the graph in Figure 3, which presents the relationships between programs and actors, the measurements of "in degree" and "out degree" stand out (Borgatti, 2005). The greatest index of "in degree" was obtained for actions in the promotion of agro-ecology, followed by: a) public irrigation projects (PPI); b) land regularization programs; c) the Food Acquisition Program (PAA); and d) the management of extractivists reserves (RESEX), which signifies that more actors participate in the operationalization of these programs. Meanwhile, the largest "out degree" was presented by the state governments, followed 
by the Special Secretariat of Family Farming and Agrarian Development (SEAD), by Incra, by organizations representing family farming and by the Ministry of Social Development (MDS), signifying that these actors participate in the largest number of evaluated programs. This index, like the others described below, demonstrates the importance of state governments to the execution of programs related to family farming.

In Figure 4, which represents the relationships between the actors, these 5 members also represent the largest page ranks, a qualified measure of the importance of the links, which considers not just the number of links of a given actor, but also the relevance of these connections (Brin \& Page, 1998).

Also in Figure 4, in terms of the "weighted degree", once again the importance of the state governments stands out. This was the actor which obtained the greatest value (degree $=121$ ), which means that this is the actor who establishes the most partnerships with other actors within the National Family Farming Policy Network. The state governments are followed by: a) organizations representing family farming (degree =114); b) SEAD (degree =107); c) Incra (degree = 104); and d) municipal governments (degree $=103$ ). The large number of actors involved is an indicator of the complexity of the environment in which these actors operate and of the high transaction costs they are incurring (Leifeld \& Schneider, 2012; Mitchell \& Shortell, 2000).

Figure 3

Graph of the National Family Farming Policy Network (actors and programs)

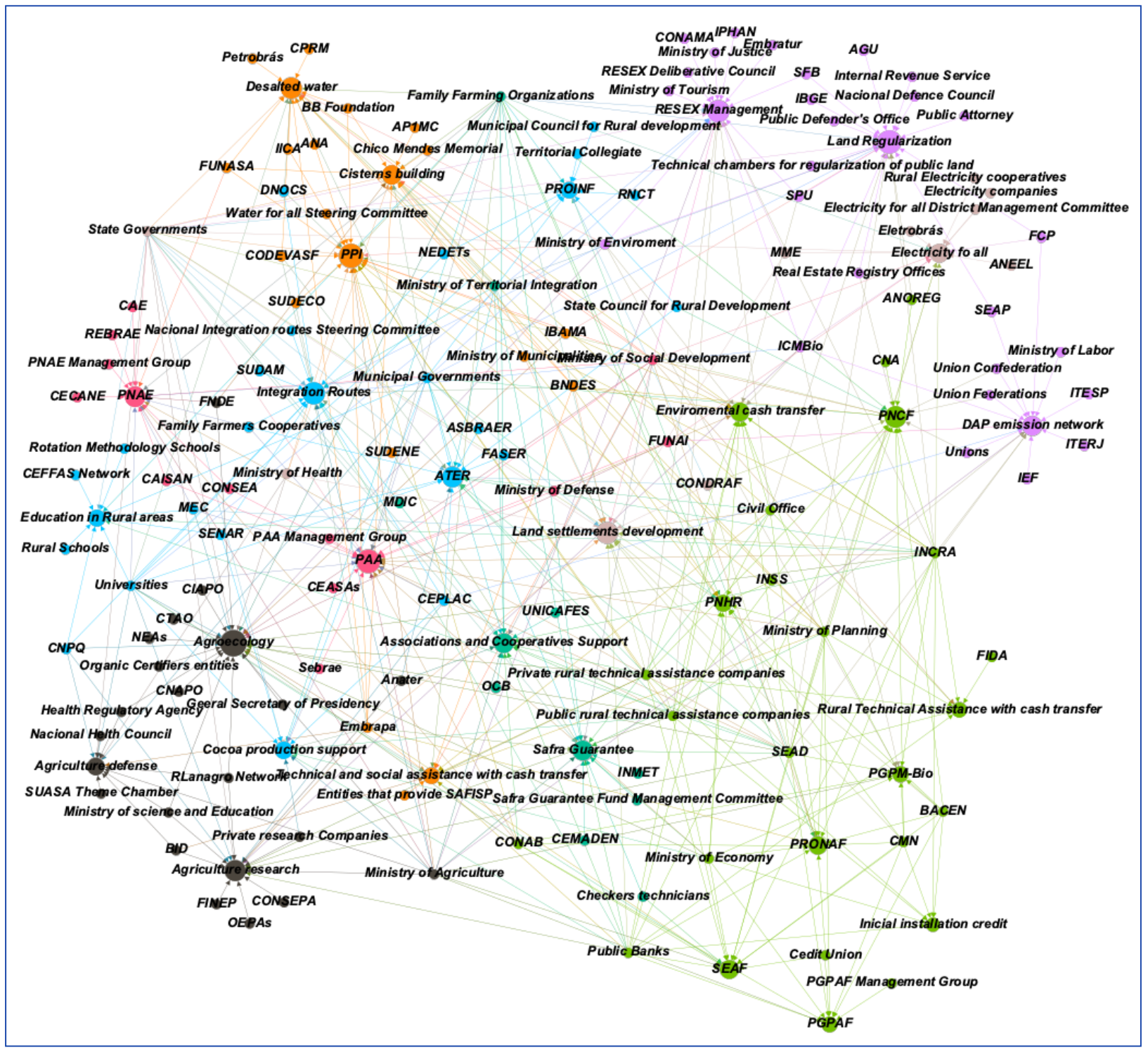

Source: Elaborated by the authors. 
Figure 4

Graph of the National Family Farming Policy Actor Network

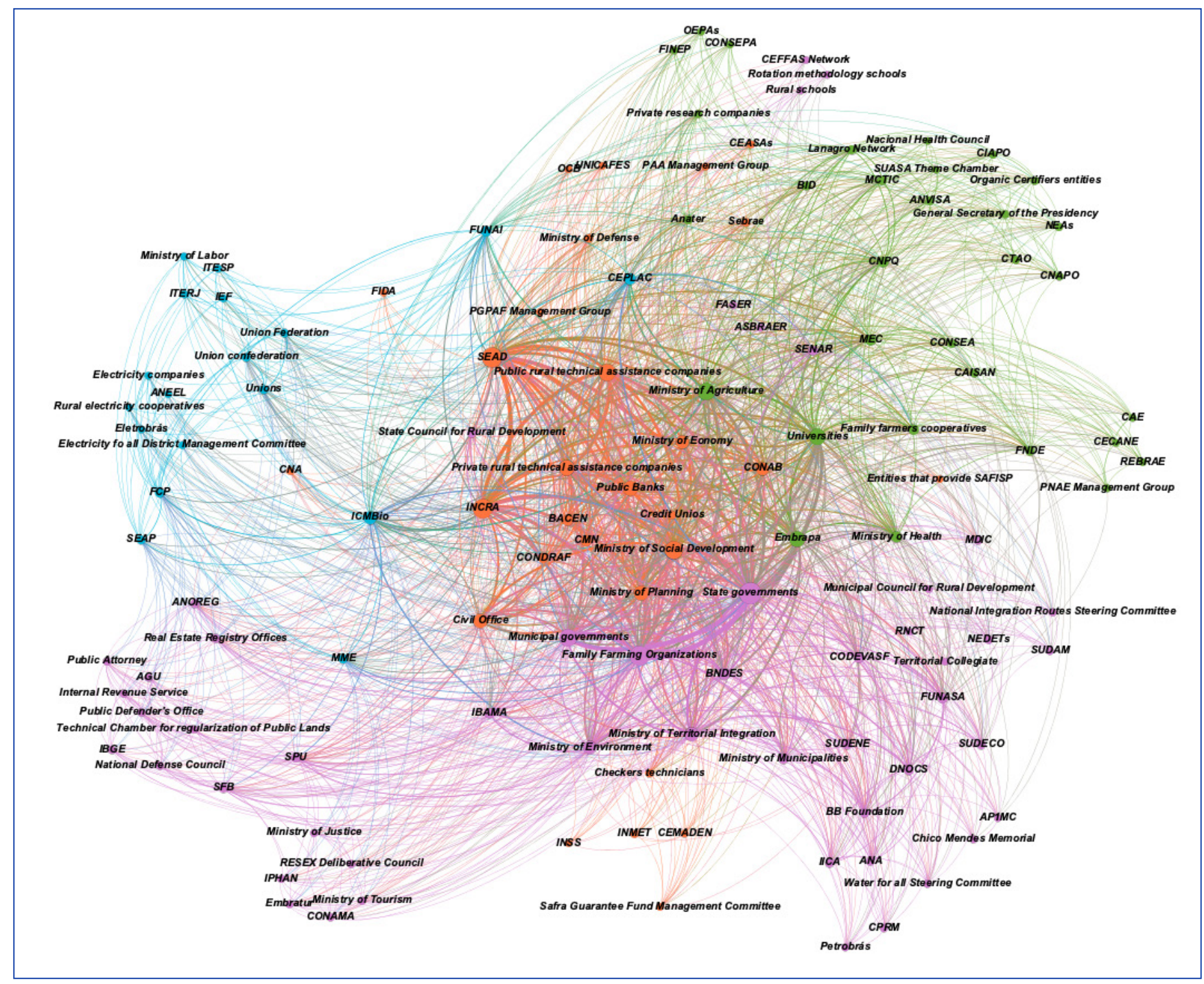

Fonte: Elaborada pelos autores.

These also were the actors who presented the largest degrees of closeness centrality (CC) and the betweenness centrality (BC), namely: a) state governments $(C C=0.941 ; B C=0.084)$; $b$ ) organizations representing family farming $(C C=0.895 ; B C=0.067)$; c) $\operatorname{SEAD}(C C=0.854 ; B C=0.067) ; d)$ Incra $(C C=0.837 ; B C=0.051)$; and e) municipal governments $(C C=0.832 ; B C=0.052)$. The high closeness centrality of an actor indicates that the average distance of its shortest paths to reach all the other actors is smaller. The betweenness centrality indicates the frequency that this actor is present in the shortest parth between two other actors. Measures of centrality indicate the most important vertices, with the greatest capacity to influence the flow of resources and information. For example, actors with high centralities of intermediation tend to be capable of activating the structural holes of a network (Burt, 1992), and can, inclusively, promote links between isolated clusters.

In terms of the graph represented by Figure 5, which explores the relationships between programs through its actors, it highlights that all of the programs obtained large degrees of integration (of the 30 programs analyzed, 20 presented the largest possible degree of relationships in this network, which is equivalent to the number of programs minus 1 , or 29). This signifies that these 20 programs have at least one actor in common with all of the other analyzed programs (Borgatti, 2005). 
Figure 5

Graph of the Programs of the National Family Farming Policy Network

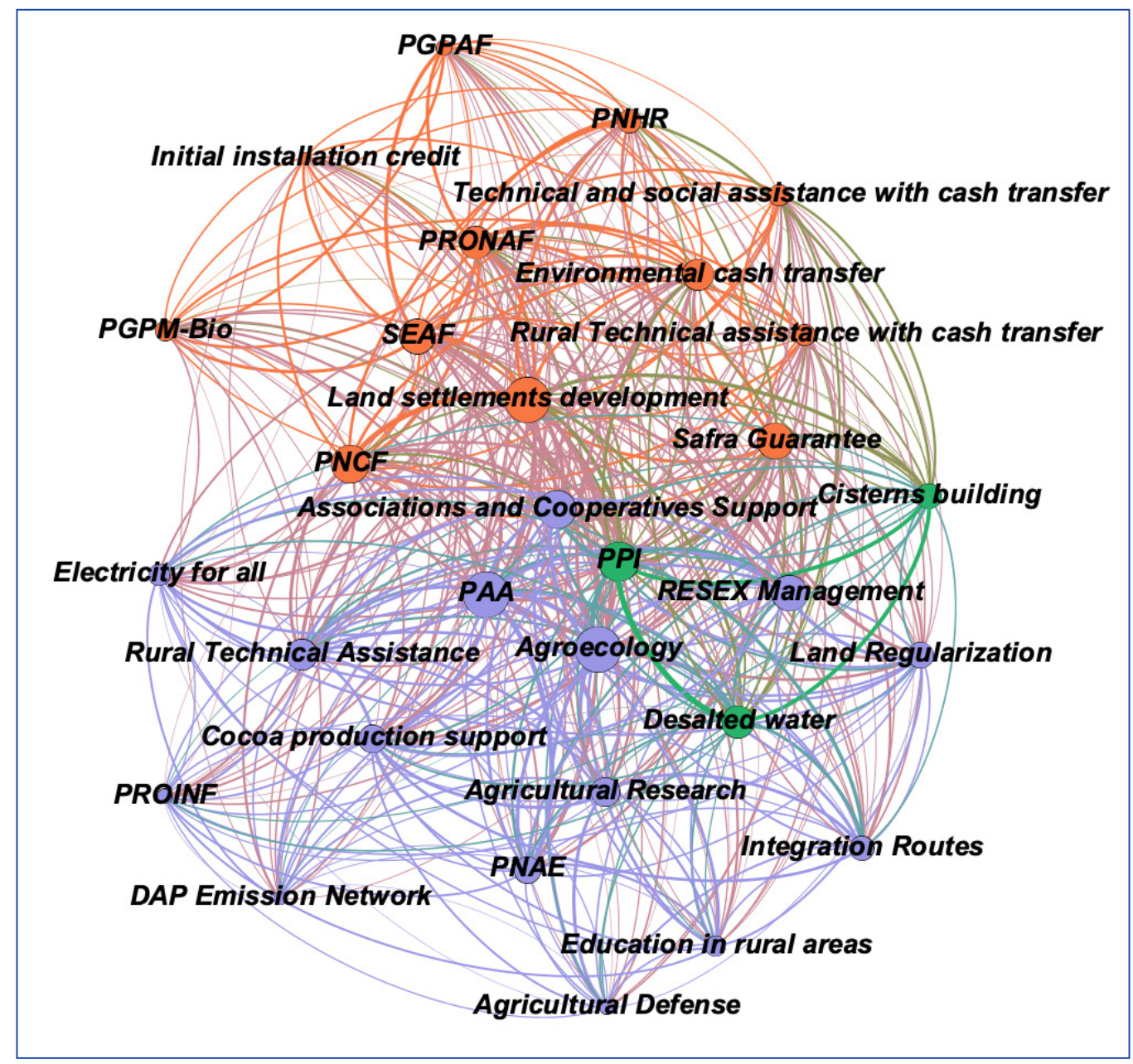

Fonte: Elaborada pelos autores.

Another measure that stands out in Graph 5 is the clustering coefficient (Barrat, Barthelemy, Pastor-Satorras \& Vespignani, 2004; Borgatti et al., 2013). The cluster of a vertex represents the group of all the other vertices linked to it. Thus, if all the neighbors of a given vertex are also linked together, the cluster coefficient will be equal to 1. According to Berardo (2009), large cluster coefficients are important assets, mainly for non-central vertices, because multiple links between a group increases the reputational cost of non-collaboration, which tends to make the environment more cooperative.

The Cisterns Building Program obtained a cluster coefficient of 0.994, which signifies that practically all of the programs which have actors in common with the Cisterns Building Program also have actors in common between them. Large clustering coefficients were also obtained for the programs: a) Inicial Installation Credit (0.993); b) Agricultural Defense (0.99); c) National Program of Food for Schools (PNAE) (0.986); and d) National Program of the Sustainable Development of Rural Territories (Proinf) (0.986).

After presenting the network representations and their principal statistics, it is fundamental to explain the main limitation of this analysis, which is the fact that it was not possible to measure the intensity of the effective participation of the various actors, in an objective way. It was possible to observe that all organizations with legal attributions in the public programs were exercing these attributions to some extent. Or in other words, there was no actor missing, who should have been acting but was not. 
However, mainly based on the interviews and the documents analyzed, it was perceived that the intensity of action of each actor varies enormously. Thus, what often happens is that the distant participation of a given Ministry or the active presence of a certain actor in some points of territory, accompanied by their virtual absence in others. Thus, the actions of the actors is not homogeneous within the various programs. It is not that they do not exercise their attributions, but often they are not that present as would be expected for the proper running of the programs.

In any event, we understand that we do not have sufficient evidence to reflect in the network graphs the instensity of the real actions of each of the actors invoved, showing which were more or less active in practice. Given this, we have opted to present the network based on the legal attributions defined for the programs, since these attributions were supported by the budgeted activities presented by the federal government's Integrated System of Financial Administration (SIAFI), by the monitoring information on implementation contained in the Monitoring of the Multiyear Plan ${ }^{10}$ or based on information from relevant interviewees.

In this manner, in light of some evidence that a given member in fact acts in a specific program, its participation in this program was considered, even in those cases in which there were indications that this participation was weak.

Recognizing the limitation of this analaysis, however, we have opted not to attribute values of participation intensity to any actor, given that this attribution would be realized in a highly subjective manner, mainly considering the territorial coverage. Thus, measuring the degree of participation on a national level is not a trivial task and requires detailed data that could not be obtained.

However, in order to seek an approximation of the real level of integration of the network actors, we sought to identify the perceptions of the interviewees in relation to this subject. In this sense, the level of network integration as presented by the interviewees is quite distant from what the legal attributions envisage. In general, in the view of the interviewees, the articulation of the actors reflected in the delivery of services is weak.

Various interviewees pointed to successful cases in local initiatives, often dependent on the effort of specific people, and other cases which resulted in the implementation of programs in a disconnected manner. This perception was also manifested by the ex-Minister of the former MDA Pepe Vargas in the $57^{\text {th }}$ Meeting of Condraf on February 19, 2014: "it's always a challenge to overcome that compartimentalized culture, with every Ministry taking care of his own turf [...] and the challenge is not only in federal level. It is also interfederative."11

Moreover, various interviewees stated that, before the extinction of the MDA, this Ministry acted to promote the articulation of actions, but afterward, the level of integration diminished even more, due to the weakening of the actor which had the responsibility to lead the process of valuing family farming.

The literature describes situations that seem to fit well into the panorama found: to Mandell and Keast (2007), in networks characterized by low levels of integration, members remain independent of each other and interact only when necessary. The links between them are loose and infrequent. According to Peters (1998), a minimal level of integration would be where the organizations are conscious of the activities of other organizations and make honest efforts not to harm the others or duplicate their efforts, which is far from managing to handle the complexity of the problems faced by the public sector.

In light of this, the design formatted by the network through the norms which define the attributions of the actors envisages a dense framework in the center and a flexible one along the margins. However, in practice, even this center has actors with variable levels of dedication to the network, both when we analyze the actions of definition of guidelines by the Ministries, and when we analyze the presence of government organs in various points of territory.

It is believed that this is due to a great extent to the fact that the various members of the network have in their sphere of action a myriad of other subjects which are not linked to family farming. Thus, given the variations of the preferences of the leadership or a scarcity of resources, sometimes the subject of family farming is prioritized and sometimes it is not. As Provan and Milward (1991) pointed out: an agency which mainly provides services to other target publics tends to be only marginally linked to the network. Thus, the excess of legal attributions compared to the capabilities of these government organs makes their effective actions difficult in relation to all of the subjects under their responsibility.

\footnotetext{
${ }^{10}$ Data available on SIOP.

${ }^{11}$ According to the transciption ipsis verbis.
} 


\section{CONCLUSION}

To properly evaluate public policies, one has to understad the way in which these policies are conducted. Thus, for policies in which coordinated actions are important to obtaining results, the analysis of public policy networks constitutes an approrpiate tool, because it helps understand the structure and context within which these policies operate.

Therefore, this approach has been applied to the Brazilian National Family Farming Policy to get to know the composition of its members and stakeholders and the characteristics of the relationships established by them, in order to shed light on the factors that can affect the achievement of the results expected by the target public.

In terms of the network's composition, we have identified a total of 76 organizational members (Provan \& Milward, 1995) and 95 external stakeholders (Mitchell et al., 1997). It is quite a heterogeneous network, which increases the legitimacy of the public policy, as long as the actors are in fact active (Mitchell \& Shortell, 2000). However, in terms of the organizations respresenting family farming, it may be perceived that these representatives have not proved to be sufficiently strong, a fact corroborated by the gradual weakening and later extinction of Condraf.

In terms of the relationships, we have identified a network which is integrated in its center and flexible on its margins, in which the group of key actors is significant to the operationalization of various programs, while a series of other actors are more dispersed and/or localized in their activities.

The principal limitation of the performed analysis is the difficulty of estimating objectively the intensity of the network actors' participation. We could demonstrate the participation of all of the actors through the programs, even though there were relevant indications of weak engagement on the part of a portion of these actors. It should be remembered that this variable level of commitment was observed not only by the actors at the margins of the network structure, but also by the actors in the central group, whose attributions are crucial to the proper functioning of these programs.

Thus, weak links appear to be frequent and pervasive, given that, it is argued that the observed distancing compromises the effective functioning of the entire network and the obtaining of the expected results of public action (O'Toole, 1997; Provan \& Milward, 1995).

Moreover, state governments stand out in various network statistics. They obtained high out degrees, participating in a large number of programs; high page rank indices, showing that their relationships are not only numerous but also relevant; and also were prominent in the centrality measures, indicating their importance and ability to influence the flow of resources and information (Burt, 1992). In light of this, the importance of the federal pact to the functioning of family farming policy should be emphasized, and it is suggested that subnational managers should have their interests and demands considered to promote the effective reach of results in programs concerned with this public.

To evaluate the scope of public policies while ignoring the context of their formulation and their management means missing the opportunity to identify important causes of any failures in terms of performance. On the other hand, shedding light on this context can signify the opportunity to improve the functioning of network relationshhips with potential positive effects on the results of the public policy.

In the case of family farming, the structure formed by the network provides useful clues to understanding the difficulties faced in the delivery of services to the various groups within this category, whose needs are so critical to subjects such as food safety and environmental preservation.

Without ignoring the differences of the various Brazilian regions on this subject, we believe that future studies should use qualitative comparative analysis (QCA) to compare effective local networks and others with worse performance, to identify best practices that can be replicated and stimulated for the benefit of family farming in the whole country. 


\section{REFERENCES}

Bardin, L. (2009). Análise de conteúdo. Lisboa: Ed. 70.

Barrat, A., Barthélemy, M., Pastor-Satorras, R., \& Vespignani, A. (2004). The architecture of complex weighted networks. Proceedings of the National Academy of Sciences, 101(11), 3747-3752.

Bastian, M., Heymann, S., \& Jacomy, M. (2009). Gephi: an open source software for exploring and manipulating networks. In Proceedings of International AAAI Conference on Web and Social Media, Palo Alto, CA.

Berardo, R. (2009). Generalized trust in multi-organizational policy arenas: studying its emergence from a network perspective. Political Research Quarterly, 62(1), 178-189.

Blondel, V. D., Guillaume, J. L., Lambiotte, R., \& Lefebvre, E. (2008). Fast unfolding of communities in large networks. Journal of Statistical Mechanics: Theory and Experiment, 10, 10008.

Borgatti, S. P. (2005). Centrality and network flow. Social Networks, 27(1), 55-71.

Borgatti, S. P., Everett, M., \& Johnson, J. (2013). Analyzing social networks. Thousand Oaks, CA: SAGE.

Brandes, U. (2001). A faster algorithm for betweenness centrality. The Journal of Mathematical Sociology, 25(2), 163-177.

Brin, S., \& Page, L. (1998). The anatomy of a large-scale hypertextual web search engine. Computer Networks and ISDN Systems, 30, 107-117.

Burt, R. S. (1992). Structural holes: the social structure of competition. Cambridge, MA: Harvard University Press.

Caume, D. J. (2009). Agricultura familiar e agronegócio: falsas antinomias. Redes, 14(1), 26-44.

Cazella, A. A., Capellesso, A. J., Medeiros, M., Tecchio, A., Sencébé, Y, \& Búrigo, F. L. (2016). Políticas públicas de desenvolvimento rural no Brasil: o dilema entre inclusão produtiva e assistência social. Política e Sociedade, 15(spe.), 49-79.

Cline, K. (2000). Defining the implementation problem: organizational management versus cooperation. Journal of Public Administration Research and Theory, 10(3), 551-571.

Da Ros, C. (2006). As políticas agrárias durante o governo Olívio Dutra e os embates sociais em torno da questão agrária gaúcha (19992002) (Doctoral Dissertation). Universidade Federal Rural do Rio de Janeiro, Rio de Janeiro, RJ.

Decreto n. 9.186, de 1o de novembro de 2017. (2017). Dispõe sobre a composição, a estruturação, as competências e o funcionamento do Conselho Nacional de Desenvolvimento Rural Sustentável. Diário Oficial da União, Brasília, DF, 3 nov. 2017, Seção 1.

Dias, M. (2007). As mudancas de direcionamento da política nacional de assistência técnica e extensão rural (PNATER) face ao difusionismo. Oikós: Revista Brasileira de Economia Doméstica, 18(2), 11-21.

Ferlie, E., FitzGerald, L., McGivern, G., \& Dopson, S. (2011). Public policy networks and "wicked problems": a nascent solution? Public Administration, 89(2), 307-324.

Fernandes, A. H. M. (2016). A Frente Ampla da Agropecuária Brasileira na Constituinte de 1988: o patronato rural e o projeto de modernização conservadora do campo. In Anais do 17o Encontro de História da ANPUH-RIO, Nova Iguaçu, RJ.

Fischer, M., \& Sciarini, P. (2015, July). Unpacking reputational power: intended and unintended determinants of the assessment of actors' power. Social Networks, 42, 60-71.

Grisa, C., \& Schneider, S. (2014). Três gerações de políticas públicas para a agricultura familiar e formas de interação entre sociedade e Estado no Brasil. Revista de Economia e Sociologia Rural, 52(supl. 1), 125-146.

Guanziroli, C. (1999). Reforma agrária e globalização da economia: o caso do Brasil. Brasília, DF: Instituto Nacional de Colonização e Reforma Agrária.

Jennings, E. (1994). Building Bridges in the Intergovernmental Arena: Coordinating Employment and Training Programs in the American States. Public Administration Review, 54(1), 52-60.

Jennings, E., \& Ewalt, J. (1998). Interorganization coordination, admistrative consolidation, and policy performance. Public Administration Review, 58(5), 417-428.

Lei n. 4.504, de 30 de novembro de 1964. (1964). Dispõe sobre o Estatuto da Terra, e dá outras providências. Diário Oficial da União, Brasília, DF, 30 nov. 1964, Seção 1.

Lei n. 8.629, de 25 de fevereiro de 1993. (1993). Dispõe sobre a regulamentação dos dispositivos constitucionais relativos à reforma agrária, previstos no Capítulo III, Título VII, da Constituição Federal. Diário Oficial da União, Brasília, DF, 26 fev. 1993, Seção 1.

Leifeld, P., \& Schneider, V. (2012). Information exchange in policy networks. American Journal of Political Science, 53(3), 731-744.

Mandell, M., \& Keast, R. (2007). Evaluating network arrangements: toward revised performance measures. Public Performance \& Management Review, 30(4), 574-597.

Mitchell, R., Agle, B., \& Wood, D. (1997). Toward a theory of stakeholder identification and salience: defining the principle of who and what really counts. The Academy of Management Review, 22(4), 853-886.

Mitchell, S., \& Shortell, S. (2000). The governance and management of effective community health partnerships: a typology for research, policy, and practice. The Milbank Quarterly, 78(2), 241-289.

Moreira, J. (2009). Uma visão do papel da agricultura familiar no Brasil. Novos Cadernos NAEA, 12(2), 57-88.

Navarro, Z. (2010). A agricultura familiar no Brasil: entre a política e as transformações da vida econômica. In J. G. Gasques, J. E. Vieira, Filho, \& Z. Navarro (Ed.), A agricultura brasileira: desempenho, desafios e perspectivas (pp. 185-211). Brasília, DF: Instituto de Pesquisa Econômica Aplicada.

O’Toole, L. (1997). Treating networks seriously: practical and researchbased agendas in public administration. Public Administration Review, 57(1), p. 45-52.

Peters, B. G. (1998). Managing horizontal government: the politics of coordination (Research Paper n. 21). Ottawa, Canada: Canadian Centre for Management Development. 
Picolotto, E. (2014). Os atores da construção da categoria agricultura familiar no Brasil. Revista de Economia e Sociologia Rural, 52(supl. 1), 63-84.

Pressman, J., \& Wildavsky, A. (1984). Implementation: how great expectations in Washington are dashed in Oakland (3a ed.). Los Angeles, CA: University of California Press.

Provan, K., \& Kenis, P. (2007). Modes of network governance: structure, management, and effectiveness. Journal of Public Administration Research and Theory, 18(2), 229-252.

Provan, K., \& Lemaire, R. (2012). Core concepts and key ideas for understanding public sector organizational networks: Using research to inform scholarship and practice. Public Administration Review, 72(5), 638-648.

Provan, K., \& Milward, H. (1991). Institutional-Level Norms and Organizational Involvement in a Service-Implementation Network. Journal of Public Administration Research and Theory, 1(4), 391-417.
Provan, K., \& Milward, H. (1995). A preliminary theory of interorganizational network effectiveness: a comparative study of four community mental health systems. Administrative Science Quarterly, 40(1), 1-33.

Raab, J., Mannak, R., \& Cambré, B. (2013). Combining structure, governance, and context: a configurational approach to network effectiveness. Journal of Public Administration Research and Theory, 25(2), 479-511.

Repetto, F. (2009). Coordinación y gestión pública integral en América Latina: notas conceptuales. In F. Repetto, H. M. S. Almeida, J. Toni, M. S. Fonseca, M. J. M. Cabello, O. O. Aguilar ... J. C. Vaz (Ed.), Reflexões para Ibero-America: planejamento estratégico (pp. 11-20). Brasília, DF: Escola Nacional de Administração Pública.

The Gephi Consortium. (c2017). Gephi: The Open Graph Viz Platform. Retrieved from https://gephi.org/

Luciana Nunes Goulart

ORCID: https://orcid.org/0000-0003-4112-8775

Master's in Administration from the Graduate Program in Administration at the University of Brasília (PPGA/UnB); Federal Auditor of External Control of the Federal Accounting Court, Brasilia -DF, Brazil. E-mail: lucianagoulart33@gmail.com

Diego Mota Vieira

ORCID: https://orcid.org/0000-0003-1275-1648

Ph.D. in Administration from the Graduate Program in Administration at the University of Brasilia (PPGA/UnB); Adjunct Professor of the Graduate Program of Administration at the University of Brasília (PPGA/UnB), Brasília - DF, Brazil. E-mail: diego1mv@yahoo.com.br

Daniela Matias de Carvalho Bittencourt ORCID: https://orcid.org/0000-0002-3137-6567

Ph.D. in Biological Sciences from the University of Brasília; Post-Doctorate in Agronomic Development Research, CIRAD, France; Researcher for Embrapa Genetic Resources and Biotechnology, Brasília - DF, Brazil. E-mail: daniela.bittecourt@embrapa.br 